\title{
ЕКОНОМІКА ЗНАНЬ: СОЦІАЛЬНО-ЕКОНОМІЧНІ ПЕРЕШКОДИ НА ШЛЯХУ ІННОВАЦІЙНОГО РОЗВИТКУ
}

\section{DOI: 10.32620/cher.2019.1.06}

Постановка проблеми. Розвинені економіки окремих держав стають прикладом та задають темпи розвитку для інших. Країни, які зараз займають лідируючи позиції, вивели на перший план людину з їі духовними, людськими та розумовими якостями. Україна поки не перейняла цей досвід та іде в протилежному напрямку знецінюючи всі види відносин в державі. Метою статті $\epsilon$ висвітлення стану організації взаємодії населення зі всіма ланками влади для розуміння та виявлення кроків на шляху до розвитку економіки знань. Об'єктом дослідження виступає соціальний комплекс умов життєдіяльності населення України, як підгрунтя формування ціннісних орієнтирів економіки знань. Основою методологічних спостережень стала практична сторона вибудованих стосунків між населенням та органами влади всіх рівнів. Гіпотезою дослідження $\epsilon$ думка про те, що кожен повинен зайняти своє гідне місце для зрушення машини під назвою Держава в сторону підвищення якості соціальних відносин, які будуть служити підвищенню економічної складової. Виклад основного матеріалу. На сьогоднішній час стан взаємодії та комунікації з органами влади вражає знеціненням та нехтуванням морально-етичними та правовими нормами. Некомпетентність органів влади та велика корумпованість всіх структур призводить до розладу відносин між всіма верствами населення. Велика антисоціальна направленість багатьох законів та реформ не дає змогу громадянину розвиватись та реалізовувати свій потенціал, бо свідомістю більшої половини населення оволоділа одна єдина думка - як вижити. Оригінальність та практична значимість дослідження. Для досягнення економічного росту та впровадження масштабно-інноваційних зрушень, потрібно почати 3 кардинальних змін в соціальній площині. Запропоновані кроки поліпшать відносини між населенням і владаю, налагодять діалог та повернуть довіру до державного апарату. Висновки досліджень. Виходячи з наведеного, для потужного соціально-економічного розвитку країни потрібно кардинально переформатувати відносини між населенням та владою, а каож керуватись здоровим глуздом приймаючи рішення, які можуть нашкодити іншій людині.

\section{Ключові слова:}

економіка знань, соціальні відносини, корупція, відкритий діалог, влада, населення.

\section{ECONOMICS KNOWLEDGE: SOCIO-ECONOMIC BURDENS ON THE WAY TO INNOVATION DEVELOPMENT}

Formulation of the problem. Developed economies of individual states are becoming an example and set the pace of development for others. Countries that are now leading the way have brought people to the forefront with their spiritual, human and intellectual qualities. Ukraine has not yet taken this experience and goes in the opposite direction, devaluing all kinds of relations in the state. The purpose of the research is to highlight the state of the organization of interaction of the population with all branches of power in order to understand and identify the steps towards the development of the knowledge economy. The object of research is the social complex of living conditions of the population of Ukraine, as the basis for the formation of value orientations of the knowledge economy. The methods used of the research were the practical side of the built relationship between the population and authorities at all levels. The hypothesis of the research is the idea that everyone should take his worthy place to shift a car called State in the direction of improving the quality of social relations, which will serve to increase the economic component. The statement of basic materials. To date, the state of interaction and communication with government is striking by the depreciation and neglect of moral, ethical and legal standards. The incompetence of the authorities and the high corruption of all structures leads to disruption of relations between all segments of the population. The great

${ }^{1}$ Машкіна Аліна Сергіївна, завідувач лабораторії кафедри «Фінанси», Національний аерокосмічний університет ім. М.С. Жуковського «Харківський авіаційний інститут», м. Харків, Україна.

Mashkina Alina, head laboratory of Finances Department National Aerospace University «Kharkiv Aviation Institute», Kharkiv, Ukraine.

ORCID ID: 0000-0002-5080-1063

e-mail: a.mashkina@khai.edu 
anti-social orientation of many laws and reforms does not allow a citizen to develop and realize his potential, as the consciousness of more than half of the population has mastered a single opinion - how to survive. The originality and practical significance of the research. To achieve economic growth and the implementation of large-scale innovation, you need to start with radical changes in the social plane. The proposed steps will improve the relations between the people and the authorities, establish dialogue and restore confidence in the state apparatus. Conclusions of the research. Based on this study, we can understand that we need to radically revise the relations between the population and the authorities and to be guided by common sense when making decisions that can harm another person.

Key words:

knowledge economy, social relations, corruption, open dialogue, power, population.

\section{ЭКОНОМИКА ЗНАНИЙ: СОЦИАЛЬНО-ЭКОНОМИЧЕСКИЕ ПРЕПЯТСТВИЯ НА ПУТИ ИННОВАЦИОННОГО РАЗВИТИЯ}

Постановка проблемы. Развитые экономики отдельных государств становятся примером и задают темпы развития для других. Страны, которые сейчас занимают лидирующие позиции, вывели на первый план человека с его духовными, человеческими и интеллектуальными качествами. Украина пока не приняла этот опыт и идет в противоположном направлении обесценивая все виды отношений в государстве. Целью статьи является освещение состояния организации взаимодействия населения со всеми звеньями власти для понимания и выявления шагов на пути к развитию экономики знаний. Объектом исследования выступает социальный комплекс условий жизнедеятельности населения Украины, как основа формирования ценностных ориентиров экономики знаний. Основой методологических наблюдений стала практическая сторона выстроенных отношений между населением и органами власти всех уровней. Гипотезой исследования является мнение о том, что каждый должен занять свое достойное место для развития государства в сторону повышения качества социальных отношений, которые будут служить повышению экономической составляющей. Изложение основного материала. На сегодняшнее время состояние взаимодействия и коммуникации с органами власти поражает обесценением и пренебрежением морально-этическими и правовыми нормами. Некомпетентность органов власти и большая коррумпированность всех структур приводит к расстройству отношений между всеми слоями населения. Большая антисоциальная направленность многих законов и реформ позволяет гражданину развиваться и реализовывать свой потенциал, потому сознанием большей половины населения овладела одна единственная мысль: «как выжить». Оригинальность и практическая значимость исследования. Для достижения экономического роста и внедрения масштабно-инновационных сдвигов, нужно начать с кардинальных изменений в социальной плоскости. Предложенные шаги улучшат отношения между населением и власть является, наладят диалог и вернут доверие к государственному аппарату. Выводы исследований. Исходя с этого исследования можем понять, что нам нужно кардинально пересмотреть отношения между населением и властью и руководствоваться здравым смыслом принимая решения, которые могут навредить другому человеку.

\section{Ключевые слова:}

экономика знаний, социальные отношения, коррупция, открытый диалог, власть, население.

Постановка проблеми. Одним 3 важливих завдань економічного зростання та прискорення інноваційної динаміки України $\epsilon$ перехід до економіки знань, яка базується на використанні знань та навичок кожного індивіда. Знання - значуще благо суспільства, що накопичується, збільшується та застосовується в практичній сфері життя населення.

В реаліях нашого часу, коли вчені та висококваліфіковані робітники виїжджають за кордон віддаючи свої знання та сили для економік інших країн, нам необхідно удосконалити правові, соціальні та економічні механізми підтримки потенціалу кожного індивідууму, який використовує власний інтелек- туальний ресурс для покращення суспільного блага. Розвиток економіки знань для нашої держави - єдиний шлях інноваційного прогресу та перехід до конкурентоспроможної економіки на основі використання інтелектуального ресурсу.

Аналіз останніх досліджень та публікацій. Першим хто запропонувув термін «економіки знань» був австрійськоамериканський вчений Фріц Махлуп. Термін був введений для типу економіки, в якій знання відіграють вирішальну роль, а виробництво знань становить джерело зростання [1, c. 15]. 
Суттєвою роботою, що дала поштовх до подальшої зацікавленості учених питанням нової економіки, була книго Д. Белла «Настання постіндустріального суспільства». В цій праці визначилось, що інформація та знання - основа постіндустріального суспільства.

Г. Беккер першим обгрунтував економічну доцільність значних капіталовкладень як державних так і приватних в людський потенціал. Він вважав, що кожна копійчина потрачена на освіту громадян, на медичне обслуговування та соціальні програми повертається прибутками [2].

Не оминула зацікавленість цим питанням українських вчених. Питанню дослідження економіки знань приділяли увагу вчені: В. Геєць, Г. Григорян, М. Зугровський, А. Чухна та інші.

Виклад основного матеріалу дослідження. Економіка знань - використання накопичених навичок, вмінь та знань індивіда для отримання матеріалізованого результату. Економіка знань притаманна п'ятому та шостому технологічному укладу [3, с. 71$]$ (табл. $1)$.

Т а б ли ц я 1

Еволюція технологічних укладів

\begin{tabular}{|c|c|c|c|c|}
\hline $\begin{array}{c}\text { Технологічні } \\
\text { уклади }\end{array}$ & Країни-лідери & Галузі-лідери & $\begin{array}{c}\text { Вихідна фаза, } \\
\text { роки }\end{array}$ & $\begin{array}{c}\text { Спадна } \\
\text { фаза, роки }\end{array}$ \\
\hline Перший & Великобританія & $\begin{array}{c}\text { Текстильна промисловість, } \\
\text { виплавляння чавуну }\end{array}$ & $1740-1763$ & $1763-1792$ \\
\hline Другий & Великобританія & $\begin{array}{c}\text { Паровий двигун, залізниці, } \\
\text { важке машинобудування, } \\
\text { хімічна галуз, електротех- } \\
\text { ніка }\end{array}$ & $1792-1815$ & $1815-1850$ \\
\hline Третій & США & $\begin{array}{c}\text { Металургія, електроенерге- } \\
\text { тика, неорганічна хімія }\end{array}$ & $1850-1873$ & $1873-1914$ \\
\hline Четвертий & США & $\begin{array}{c}\text { Авіа та автобудування, орга- } \\
\text { нічна хімія }\end{array}$ & $1914-1945$ & $1945-1973$ \\
\hline П'ятий & США, СС, Схід- & $\begin{array}{c}\text { Обробка інформації, елект- } \\
\text { роніка, телекомунікації, ро- } \\
\text { бототехніка }\end{array}$ & $1973-2000$ & $2000-2026$ \\
\hline Шостий* & США та інші & Нано і біотехнології & $2026-2050$ & $2050-2080$ \\
\hline
\end{tabular}

* перелік країн-лідерів стосовно шостого укладу остаточно не сформовано

Джерело: узагальнено автором на підставі [3, с. 71]

Саме людина $є$ рушієм всіх процесів свого життя. Важливим є здатність людини до осмислення, засвоєння та переробки знань які вона отримує під час життя.

Виокремлено види знань людини [4, с. 62]: повсякденні знання; наукові знання; інтуїтивні знання; релігійні знання; креативні знання. Будь-який 3 цих видів знань потрібно підтримувати та розширювати. Таким чином можемо зробити висновок що фактором розвитку людини - $\epsilon$ змістовно-якісна освіта. Цей процес починається коли дитину віддають до дитячого садочка де маленька людина вчиться комунікувати та вибудовувати взаємовідносини зі своїм оточенням. Дитячий садок - перша важлива ступінь освіти в житті людини де вона привикає до того що ії світ (простір) це не тільки батьки та родичі. Далі дитина переходить на наступний рівень освіти ідучи до школи. Після школи вже більш менш сформована особистість вибирає майбутній шлях вибираючи на яку спеціальність поступити у вищий навчальний заклад.

Але наразі не все так злагоджено в системі формування особистості. На шляху становлення особистості є багато перешкод. Одна 3 них - це недосконалість та на сам перед корумпованість державних установ до яких в процесі життя звертається людина.

Корупція в Україні нині має ознаки корупції кризового типу, яка породжується кризою сучасного українського суспільства; вона здатна поглиблювати цю кризу, маючи властивість зводити нанівець будь-які політичні, економічні, моральні реформи в Україні. Корумповані відносини дедалі інтенсивніше витісняють правові, етичні відносини між людьми, 3 аномалії поступово перетворюються на правило поведінки, що $є$ недопустимим у правовій державі [5, с. 296]. 
В закладі державної форми власності праюють такі ж самі люди. Які ж причини можуть штовхати їх на вимагання хабара? У першу чергу, це невиплата заробітної плати (табл. 2).

Сума заборгованості з виплати заробітної плати у 2019 році ${ }^{1}$

Т а бли ц я 2

\begin{tabular}{|l|r|r|}
\hline \multicolumn{1}{|c|}{ Показник } & Січень & \multicolumn{1}{c|}{ Лютий } \\
\hline Україна & 2645,1 & 2614,3 \\
\hline Вінницька & 11,9 & 15,0 \\
\hline Волинська & 17,7 & 16,4 \\
\hline Дніпропетровська & 133,9 & 138,1 \\
\hline Донецька & 467,3 & 513,6 \\
\hline Житомирська & 6,3 & 5,0 \\
\hline Закарпатська & 3,2 & 3,2 \\
\hline Запорізька & 190,3 & 177,2 \\
\hline Івано-Франківська & 23,1 & 23,4 \\
\hline Київська & 138,1 & 141,9 \\
\hline Кіровоградська & 7,1 & 8,5 \\
\hline Луганська & 505,9 & 505,4 \\
\hline Львівська & 75,5 & 42,0 \\
\hline Миколаївська & 103,2 & 91,8 \\
\hline Одеська & 63,6 & 58,1 \\
\hline Полтавська & 47,6 & 51,5 \\
\hline Рівненська & 27,2 & 17,9 \\
\hline Сумська & 275,3 & 284,0 \\
\hline Тернопільська & 13,4 & 14,7 \\
\hline Харківська & 271,5 & 275,7 \\
\hline Херсонська & 29,1 & 16,1 \\
\hline Хмельницька & 13,3 & 13,6 \\
\hline Черкаська & 58,5 & 43,7 \\
\hline Чернівецька & 0,1 & 0,1 \\
\hline Чернігівська & 17,2 & 12,2 \\
\hline м. Київ & 145,0 & 145,3 \\
\hline
\end{tabular}

${ }^{1}$ Без урахування тимчасово окупованої території Автономної Республіки Крим, м.Севастополя та частини тимчасово окупованих територій у Донецькій та Луганській областях

Джерело: [6]

Борги по заробітній платі державного сектору не $\epsilon$ виправданням робітників чи службовців для викачки грошей з громадянина який звернувся за отриманням послуги.

В рамках дослідження «Стан корупції в Україні», яке було проведене Київським міжнародним інститутом соціології (КМІС) протягом травня-вересня 2018 року найбільш корумпованими сферами життя на думку населення є (5): судова система $(62,2 \%)$; сфера отримання медичних послуг (55\% респондентів назвали дуже корумпованою), прокуратура $(54,3 \%)$; митна служба (51,6\%). Лідируючи позиції за рейтингом корумпованості займають Верховна Раду (73,2 \%), Кабінет Міністрів $(67,6 \%)$ та Президент і його адміністрація (66,1\%). Також лідерами у вимаганні хабара $є$ вищи навчальні заклади $(52,1 \%)$ та загальноосвітні школи (36,8\% ) [7].

Приведене соціологічне опитування показує що всі державні структури служать одній меті - нанесенню свідомої шкоди громадянину. Узагальнити всі види та прояви корупції в державних установах 3 якими стикається людина впродовж життя мабуть не можливо, але потрібно виділити перші прояви корупції починаючи з народження людини (табл. 3).

Дитина йде до школи, батьки дають «благодійні» кошти на ремонт класу та окремо на ремонт школи раз на рік впродовж 12 років. А от потім при здачі зовнішнього незалежного тестування можна побачити якість загальної освіти порівнявши бали $3 \mathrm{HO}$ та оцінку з атестату. 
Т а б ли ц я 3

\begin{tabular}{|c|c|c|}
\hline \multicolumn{3}{|c|}{ Ситуаційне висвітлення корупції ${ }^{3}$ яким стикається людина від народження } \\
\hline $\begin{array}{l}\text { Етапи } \\
\text { життя }\end{array}$ & $\begin{array}{l}\text { Державна } \\
\text { структура }\end{array}$ & Приклади розповсюджених видів корупції \\
\hline \multirow[t]{2}{*}{ Народження } & Медицина & $\begin{array}{l}\text { Все починається з вибору лікаря, який буде приймати поло- } \\
\text { ги, коли треба виділити йому кругленьку суму щоб все } \\
\text { пройшло добре. Далі пишеться список котрий треба принес- } \\
\text { ти для відділення, як правило це бинти, перекис, мило, набір } \\
\text { шприців і т.п. Далі за кожну проведену маніпуляцію, прине- } \\
\text { сення дитини на годування, чи поставити капельницю мед- } \\
\text { сестрі теж треба «позолотити руку». }\end{array}$ \\
\hline & $\begin{array}{c}\text { Реєстраційні } \\
\text { органи }\end{array}$ & $\begin{array}{l}\text { Наступний етап - звернення батьків до установ які реєстру- } \\
\text { ють нового громадянина, та в кращому випадку батькам це } \\
\text { звернення обійдеться коробкою цукерок }\end{array}$ \\
\hline \multirow[b]{2}{*}{ Дитинство } & Медицина & $\begin{array}{l}\text { Для оформлення дитини до дитячого садочка потрібно прой- } \\
\text { ти медичне обстеження як дитині так і матері, якщо педіатри } \\
\text { завжди проводять обстеження дитини то мати за певну суму } \\
\text { може оминути обстеження. }\end{array}$ \\
\hline & $\begin{array}{l}\text { Дитячий садочок } \\
\text { (державної чи } \\
\text { комунальної фо- } \\
\text { рми власності) }\end{array}$ & $\begin{array}{l}\text { Кожен батько чи мати приходять до директора дитячого са- } \\
\text { дочка взяти перелік документів, які потрібні для оформлення } \\
\text { дитини до дитячого садочка. С переліком документів батьки } \\
\text { отримують список що потрібно купити для групи в якій буде } \\
\text { навчатись дитина. Це може бути будь що: починаючи з по-- } \\
\text { суду на всю групу дітей, постільної білизни на всіх, стільців } \\
\text { тощо, придбавши всі необхідні документи оформлюються } \\
\text { дуже швидко, якщо ні, то директор затягує оформлення до- } \\
\text { кументів. }\end{array}$ \\
\hline
\end{tabular}

${ }^{\top}$ Приведені види корупції (вимагання хабарів за послуги які надають державні установи) - $\epsilon$ реальними прецедентами $з$ життя українців.

Джерело: розроблено автором

Не вдаючись у поглиблення корупції яка чекає на майбутніх студентів, бачимо що від народження маленький Українець вже комусь повинен щось «занести» спочатку борг за нього віддають батьки а потім він сам все життя тяжко працює щоб скопити гроші для звернення в певну державну установу. Складається враження що сформована схема «людина - звернення до державних установ «благодійні» внески - надання послуг» вже закладено до коду ДНК Українця.

Люди вже зневірились та знаходяться у стані апатії тому не чинять супротив цій жахливій ситуації яка склалась та загострилась в останні роки.

Більша частина населення не живе а думає як вижити, прокормити себе і дітей якщо вони $\epsilon$, заплатити за комунальні послуги щоб за борги на перекрили всі вентилі або не притягли до суду де звичайний Українець не найде захисту та справедливого правосуддя бо Феміда вже давно покинула судову систему України.
Вся ця корупційна ланка тягнеться до самої верхівки влади. Міністри, депутати, очільники профільних відомств не ведуть прямий предметний діалог 3 населенням, тільки через голубий екран годуючи нас обіцянками. Зміни треба починати 3 верхівки як то кажуть «риба гниє 3 голови». Спочатку треба запровадити тестування кожного державного службовця на соціальну адаптованість, щоб виявити справжні наміри людини яка йде на державну службу.

Нам потрібні керманичі країни в яких буде освіта за профілем, навички та вміння які будуть застосовуватись в практичній сфері для покращення суспільного блага, самовідданість, нам потрібні люди в яких буде прагнення до розвитку розумових та людських якостей даючи приклад іншим, як досягти покращення складових сфер життя. Після змін в соціальній площині наступлять зміни в економічній. Люди почнуть жити а не вижити. Появляться думки суттєво іншого характеру. 
Першочергове завдання для вище викладених трансформацій - це ввести інновацію «людяності» та «здорового глузду».

Інновація «людяності» та «здорового глузду» - кожна людина повинна правдиво і чітко розуміти на що вона здатна, до чого у неї $є$ хист та здібності, розуміння в якій сфері вона принесе користь і як вона допоможе покращенню суспільного блага через духовне, соціальне та інтелектуальне зростання. Можемо представити що держава це - машина, яка практично на межі стану, коли ремонту вже не підлягає. Наразі спостерігаємо недосконалість устрою держави, де більша кількість людей знаходиться не на своєму місці. За трансформаціями кожної людини повинні стояти трансформації влади та державного апарату. Насамперед потрібно зробити прозорим бюджет країни для соціальнозначущих сфер - охорони здоров'я та освіти всіх ступенів.

Недовіра населення до того як влада розподіляє бюджет який наповнюється 3 податків громадян та як він іноді осідає в кишенях чи на рахунках чиновників профільних міністерств чи відомстві на які були виділені кошти - дуже висока.

Основними ознаками недовіри є:

- тіньовий ринок праці - люди не хочуть платити податки державі, яка не захищає, не лікує, не надає якісної освіти для подальшого особистого росту;

- кількість грошових переводів громадян, які виїхали за кордон на заробітки та пошук кращих умов життя.

Треба розробити сайт щоб кожний громадянин зайшовши на нього та в режимі реального часу зміг відстежити:

-суму 3 державного бюджету виділену на цю сферу;

- розподіл суми за областями;

- рахунки всіх установ чи міських рад на яки вони були переведені для подальшого розподілу;

-відображення як розпорядилися цими коштами (відображення кожної грошової операціі).

-відображення цільових коштів у кінцевого одержувача (школи, лікарні, інститути, університети).

Далі вже структурне відображення за кожною державною установою коли, скільки та на що було потрачено фінансування.

Найважчим завданням з боку влади є: -формування відкритого діалогу шляхом запровадження референдумів для кожного значущого кроку, офіційних опитувань та соціально-орієнтовних реформ на практиці а не на словах;

-узгодження інтересів різних груп населення;

-захист цих інтересів у правовому полі;

-забезпечення умов реалізації кожного громадянина;

-консолідувати інтереси суспільства 3 інтересами влади.

Висновки та перспективи подальших досліджень. Враховуючи вище викладений матеріал, можемо зробити висновки, що запровадження інноваційних процесів для покращення соціально-економічної складової шляхом використання знань та навичок кожного індивіда стикається 3 перешкодами, які лежать у площині влади та державного устрою:

-жахливим $є$ той факт, що корупція починається 3 верхівки влади та стала нормою відносин між громадянином та державними установами;

-недолугість взаємодії між всіма ланками державних установ;

-приймання безглуздих та недієвих законів і реформ, котрі інколи ідуть в розріз з моральними, етичними та духовними нормами;

-збагачення службовців за рахунок бюджетних коштів;

-укорінення традиції - обирати чи проштовхувати на посади родичів, кумів, сватів.

-керування свідомістю громадян шляхом маніпуляції.

Влада потрібна створювати умови а не чинити перешкоди для реалізації кожного громадянина. Для того щоб Українська економіка базувалась на знаннях і стала конкурентоспроможною потрібно щоб людина віддаючи свої знання на зростання суспільного добробуту була впевнена в:

-якості медичних послуг та професіоналізмі лікарів;

-якості та доступності освітянських послуг всіх ступенів;

-чесному та справедливому судочинстBi.

Влада повинна створити мотиваційне підгрунтя для активізації населення та почати робити кроки до зближення. 
В подальшому дослідження автора будуть спрямовані на виявлення позитивних тенденцій соціально-економічної сфери, як індикатора формування економіки знань, покращення економічного стану та інноваційного ривку для України.

\section{Література}

1. Онишко С. В. Фінансове забезпечення інноваційної діяльності : навчальний посібник / С. В. Онишко, Т. В. Паєнтко, К. I. Швабій. - К.: КНТ, 2008. - 256 с.

2. Беккер Г. С. Человеческое поведение. Экономический подход. Избранные труды по экономической теории / Пер. с англ., сост., науч. Р. И. Капелюшников. - М.: ГУВШЭ. 2003. $-672 \mathrm{c}$.

3. Божко В. П. Проблеми інноваційнотехнологічного оновлення виробництва / В. П. Божко, Н. 3. Карацева, А. С. Машкіна // Держава та регіони. - 2018. - № 5 (104). - С. 69 74.

4. Малюкіна А. О. Теоретичні аспекти знань та класифікація їх видів / А. О. Малюкіна // Економіка і регіон. - 2014. - № 3. - С. 62-66.

5. Кардаш О. Я. Корупція в Україні / О. Я. Кардаш // Порівняльно-аналітичне право. 2018. - № 2. - C. 296298.

6. Демографічна та соціальна статистика // Офіційний сайт Державної служби статистики України [Електронний ресурс]. - Peжим доступу:

http://ukrstat.gov.ua/express/expres_u.html

7. Українці вважають найбільш корумпованою сферою життя суди, серед органів

Стаття надійшла

до редакції : 01.03.2019 p. влади - Верховну Раду // Інформаційне агенство «Інтерфакс Україна» [Електронний ресурс]. https://ua.interfax.com.ua/news/political/533657. html

\section{References}

1. Onyshko, S. V. \& Paientko, T. V. \& Shvabii, K. I. (2008). Financial providing of innovative activity: Train aid. Kyiv: KNT, 256.

2. Becker, G. S. (2003). Human behavior: Economical approach. Selected works on economic theory. Moscow: HSE Publishing House, 672.

3. Bozhko, V. P. \& Karatseva, N. Z. \& Mashkina, A. S. (2018). Problems of the innovative-technological updating of production. Zaporizhia: Classical Private University, 69-74.

4. Maliukina, A. O. (2014). Theoretical aspects of knowledge and classification of their kinds. Poltava: Poltava National Technical Yuri Kondratyuk University, 62-66.

5. Kardash, O. Y. (2018). Corruption in Ukraine. Editor O. Y. Kardash. Uzhgorod: Uzhhorod National University, 296-298.

6. Demographic and social statistics. Official web site of the State Statistics Service of Ukraine. Retrieved from: http://ukrstat.gov.ua/express/expres_u.html

7. Ukrainians consider courts as the most corrupt sphere of life, among authorities Verkhovna Rada. Interfax Ukraine Information Agency. Retrieved from: https://ua.interfax.com.ua/news/political/533657. html

\footnotetext{
Стаття прийнята

до друку: 29.03.2019 р.
}

Бібліографічний опис для цитування :

Машкіна А. С. Економіка знань: соціально-економічні перешкоди на шляху інноваційного розвитку / А. С. Машкіна // Часопис економічних реформ. - 2019. - № 1 (33). - С. 45-51. 